AJEB

6,1

26

Received 1 February 2021

Revised 13 September 2021 Accepted 28 October 2021

\section{Does the monetary policy have any short-run and long-run effect on economic growth? A developing and a developed country perspective}

\author{
Md. Sayemul Islam \\ Faculty of Agricultural Economics and Rural Sociology, \\ Bangladesh Agricultural University, Mymensingh, Bangladesh \\ Md. Emran Hossain \\ Department of Agricultural Finance and Banking, \\ Bangladesh Agricultural University, Mymensingh, Bangladesh, and \\ Sudipto Chakrobortty and Nishat Sultana Ema \\ Faculty of Agricultural Economics and Rural Sociology, \\ Bangladesh Agricultural University, Mymensingh, Bangladesh
}

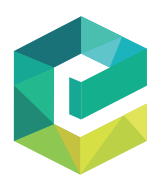

Asian Journal of Economics and Banking

Vol. 6 No. 1, 2022 pp. $26-49$

Emerald Publishing Limited e-ISSN: 2633-7991

p-ISSN: 2615-9821

DOI 10.1108/AJEB-02-2021-0014

\begin{abstract}
Purpose - The study aims to empirically examine the relationship between monetary policy and economic growth, as well as to explore the long-run and the short-run effect of monetary policy on the economic growth of a developing country (Bangladesh) and a developed country (the United Kingdom).

Design/methodology/approach - Depending on data availability, the study employed secondary data covering the period of 1980-2019. The augmented Dickey-Fuller test and the Phillips-Perron test were used for the stationarity test. Further, the $F$-bounds test was run to justify the long-run relationship between monetary policy and economic growth. Thereafter, long-run coefficients were revealed from the auto-regressive distributed lag (ARDL) model and short-run coefficients from the error correction model. Furthermore, the vector error correction model (VECM) Granger causality approach was employed to demonstrate the causality of studied variables. Lastly, different diagnostics tests ensured the robustness of the models.

Findings $-F$-bounds test outcomes suggest that monetary policy has a long-run relationship with economic growth in both countries. Long-run coefficients revealed that money supply has a positive long-run impact on economic growth in both countries. Unlike the UK, the exchange rate exhibits an adverse effect on the economic growth of Bangladesh. The bank rate seems to promote economic growth for the UK. Findings also depict that increase in lending interest rates hurts the economic growth for both countries. Besides, the short-run coefficients portray random effects at different lags in both cases. Lastly, causality among studied variables is revealed using the VECM Granger causality approach.
\end{abstract}

Originality/value - The novelty of this study lies in consideration of both developing and developed countries in the same study.

Keywords ARDL model, Monetary policy, Economic growth, Granger causality, Bangladesh,

United Kingdom

Paper type Research paper

(C) Md. Sayemul Islam, Md. Emran Hossain, Sudipto Chakrobortty and Nishat Sultana Ema. Published in Asian Journal of Economics and Banking. Published by Emerald Publishing Limited. This article is published under the Creative Commons Attribution (CC BY 4.0) licence. Anyone may reproduce, distribute, translate and create derivative works of this article (for both commercial and non-commercial purposes), subject to full attribution to the original publication and authors. The full terms of this licence may be seen at http://creativecommons.org/licences/by/4.0/legalcode. 


\section{Introduction}

The monetary policy includes several policies by which a country controls its money stock to achieve macroeconomic goals. Sound monetary policy aims to ensure inflation stability, keeping the balance of payments intact, reduce wages, attain financial growth and economic development (Criste and Lupu, 2014; Akalpler and Duhok, 2018). Monetary policy plays a significant role in developing countries' economic growth by influencing the cost and availability of credit, inflation management, and payment stability (Bondarchuk and Raboshuk, 2020; Twinoburyo and Odhiambo, 2018a). For instance, in Bangladesh, the government has always depended on monetary policy as a way to acquire economic growth (Rahman et al., 2019). The responsibility for formulating and executing monetary policy in Bangladesh lies with the Bangladesh Bank. The prime role of Bangladesh's monetary policy is to maintain fair price stability, ensure a stable balance of payments, maintain Bangladeshi taka's external competitiveness, and achieve sustainable economic growth through increased productivity, employment, and real income (Alam, 2015). Notable reforms have occurred in Bangladesh's regulatory, structural and financial policy system in the 1990s (Shah, 2009). These modifications enable Bangladesh Bank to conduct monetary policy based on marketbased instruments and blunt instruments to achieve smooth financial intermediation (Ahmed and Islam, 2004). However, Bangladesh Bank often puts itself in a detrimental situation to manipulate the monetary policy to foster its productive resources' economic growth and development (Barkawi and Monnin, 2015).

In the developed countries, the foremost aspects of monetary policy are price stability;and price stability is achieved when inflation remains low and stable for an extended period (Li et al., 2010; Fourcans and Vranceanu, 2007). Notably, price stability is the notion of being a precondition for high economic growth and employment (Angeriz and Arestis, 2007). The monetary policy of the United Kingdom (UK), for example, is set with the assistance of the Bank of England's Monetary Policy Committee (MPC). The motive of the monetary policy of the UK is low inflation (Agbonlahor, 2014). The UK tries to keep inflation close to $2 \%$ (between 1 and 3\%). Low inflation is viewed as an imperative factor in enabling higher investment in long-term and sustainable economic growth (Pettinger, 2020). The main challenge of the UK's monetary policy is to maintain sustainable economic growth by creating a high employment level in the economy (Angeriz and Arestis, 2007). Subject to the primacy of maintaining economic growth, the monetary policy must support the government's economic policy, including its economic growth and employment objectives in the UK (Bean and Jenkinson, 2001).

Despite all this evidence and claims on the performance of the monetary policy and its effect on economic growth, the objectives of this study are to trace out whether monetary policy and economic growth have a relationship in Bangladesh and the UK, and to assess the long-run and short-run impact of monetary policy on the economic growth. This study is conducted using country-wise times series data covering the period of 1980-2019. Although many previous studies have covered different aspects of the monetary policy with regard to economic development, to the best of our knowledge, this is the first study that considers not only the long-run and short-run effect of monetary policy on economic growth but also attempts to determine the nexus between monetary policy and economic growth; and draw a comparison between developing and developed country in this respect. This study considered the UK as a developed country and Bangladesh as a developing country to make a better comparison. These countries were selected due to several reasons. Historically, Bangladesh was a part of British rule. Following the British regime, Bangladesh has undergone magnificent success in reaching the height of a developing nation even after the fall of Pakistan's rule. On the other hand, the UK, an indispensable developed nation globally, continues to sustain its growth. With this in mind, we endeavored to study the role of monetary policy on the economic growth of these countries, which are historically juxtaposed
Monetary policy and economic growth 
AJEB

6,1

in terms of institutional laws and colonial virtues. Furthermore, all of the analyzed variables' data were available for these countries, with the exception of a few others. Against this background, we considered these two countries as representative of our study to determine how monetary policy actually influences their economy and whether the monetary policy works the same way in both cases. This study expects that monetary policy instruments will have a different level of impact on economic growth. If this expectation is found to be true, this study comes up with some overture that the policymakers of developing and developed countries can deal with while making economic growth-related policies. However, this paper aims to contribute to the existing literature on monetary policy in several ways. First, this study makes a significant contribution to economic theories by offering empirical proof of the importance of Keynesian liquidity preference and classical monetary theory in regulating money supply and economic growth in both developing and developed economies contexts. Second, in empirical view, to the best of the authors' knowledge, this is the first attempt to examine the nexus between monetary policy and economic growth in the aforementioned countries while also comparing selected emerging and advanced economies using time series data.

The remainder of this paper is organized as follows: The following section demonstrates the extensive review of the literature and formulates the research gaps of the study. Section 3 provides the description of the data, the modeling and the methods used in the study. Section 4 covers the empirical findings and discussion, and Section 5 concludes the paper.

\section{Literature review}

This section reviews the theoretical framework and empirical research on the relationship between monetary policy and economic growth. There are several ways via which the stance of monetary policy is conveyed into the real economy and influences the economic growth of a country. The theoretical and empirical research works on the association between monetary policy and economic growth are discussed in the following.

\subsection{Theoretical review underpinning this study}

The central bank of a country formulates monetary policy that focuses on long-term interest rates, real exchange rates, and price stability, as well as economic growth, full employment, smoothing the economic cycle, and averting financial crises. The monetary policy has several instruments such as interest rate policy, bank reserve, lending rate, open market operation, etc., which influence the economic growth of a country. Economic growth and monetary policy theories have advanced quickly over time. However, it even predates as far back to the classical quantity theory of money (QTM) (Gali, 2015). On the other hand, modern theories did not emerge until the 1930s; after that, it came to the fore with the Keynesian liquidity preference theory (Arestis and Sawyer, 2008). The classical monetary theory is the earliest prominent theory of monetary policy based on the Irving Fisher QTM, which establishes the framework for the link between monetary policy and economic variables (Twinoburyo and Odhiambo, 2018a). Since both the velocity of money and the output of the economy are assumed to be constant under QTM, any rise in the money supply will lead to a proportional increase in prices. Besides, the long-term growth of the economy was only influenced by real factors, and the money supply is neutral in both the short and long run (Gali, 2015). However, Keynes argued that the velocity of money is unstable and not constant, and hence rejected the quantity theory both conceptually and as a tool of practical policy (Keynes, 1936). The money supply was considered to be exogenous in Keynesian liquidity preference theory, and any rise in the money supply would result in a lower interest rate. Lower interest rates positively affect the marginal efficiency of investment and capital flow, resulting in output expansion and 
economic growth (Backhouse and Bateman, 2011). However, the monetary policy helps government authorities in a market economy routinely affect the direction and speed of overall economic activity, which includes not only the amount of aggregate output and employment but also the price stability (Friedman, 2000). In classical theory, money plays a passive role in determining economic growth. Hence, money as a source of investment or capital stock cannot be overlooked in defining economic growth. Tobin (1965) demonstrated that a rise in the money supply might contribute to higher growth. Putting it simply, increased money supply results in inflation, which lowers the own rate of return on money and promotes a portfolio shift toward real capital. This leads to a rise in capital stock and a greater output level per person in the long term. Therefore, the Hicks-Keynes framework adopts money supply and interest rate as instrumental variables representing monetary policy (Friedman, 1990).

\subsection{Monetary policy and economic growth nexus}

Multitudinous studies had shed light on the monetary policy and empirically adjudged its impact on economic growth in the case of different nations. Analyzing the influence of monetary policy on economic development, some articles have argued that monetary policy has tenuous or no effects on economic growth. For example, Mutuku and Koech (2014) intended to depict the effect of monetary and fiscal policy shocks on the economic advancement of Kenya for time-series data from 1997-2010 by adopting the recursive vector autoregressive (VAR) approach. They deducted that money supply and short-term interest rate denoted as monetary policy instruments are insignificant in affecting the real output. Similarly, Kamaan (2014) conducted another analysis using the VAR method which has shown that monetary policy does not impact Kenya's economic development. In their research on time series data covering the period from 1959 to 2008, Lashkary and Kashani (2011) unveiled the same disclosure in the case of Iran as they found no substantive proof of the interrelationship between money supply, economic development, wages and real economic variables.

However, a wide-ranging number of studies ascertained the pivotal role of monetary policy in economic growth. Nouri and Samimi (2011) investigated the association between monetary policy and economic growth in Iran using the ordinary least square (OLS) method and found a significant and positive relationship among them. Oneyiwu (2012) found that money supply has a positive effect on economic growth in Nigeria. A similar outcome found previously (e.g. Kareem et al., 2013) in the case of Nigeria delineated that increase in broad money and narrow money representing monetary policy propel economic growth.

Yet, some research works revealed a mix of both significant and insignificant impacts of monetary policy on economic growth. Precious and Makhetha-Kosi (2014) conducted a study to explore the role of monetary policy in propelling the economic growth of South Africa, taking cognizance of the period 2000-2010. Analyzing the data with vector error correction model (VECM) and error correction model (ECM) approach, they substantiated that the money supply, the repo rate and the exchange rate do not significantly foster economic growth, whereas the inflation rate exerts a significant positive role in determining the economic advancement of South Africa. Mugableh (2019) scrutinized the equilibrium and dynamic causality association among economic growth and monetary policy tools in Jordan from 1990 to 2017. Findings revealed from the ARDL model indicated that except inflation rate, money supply and real interest rate promote economic growth both in the short run and long run. Moreover, the VECM approach outcome assured a bidirectional causal relationship between monetary policy variables and economic growth. Ufoeze et al. (2018) empirically tested the impact of monetary policy on the economic growth of Nigeria. The findings showed that money supply significantly promotes economic growth, whereas monetary policy rate, interest rate and investment showed an insignificant influence on economic growth.
Monetary policy and economic growth 
AJEB

6,1

\subsection{Monetary policy and economic growth of Bangladesh}

This section presents some works of the literature that provide insights on Bangladesh's monetary policy and the economy, as it represents the developing country in our study. There are some studies in Bangladesh encompassing monetary policy. Hossain and Ibon (2020) attempted to analyze the effectiveness of monetary policy in Bangladesh by identifying various transmission channels. Noman and Khudri (2015) analyzed the impact of monetary policy and fiscal policy on the economic growth of Bangladesh over the period from 1979-80 to 2012-13 by employing an OLS approach and correlation matrix technique. They concluded that monetary policy variables are positively correlated with economic growth. However, they did not conduct the test unit root of the variables. Also, they did not investigate the long-run and short-run effects of monetary policy on economic growth. Rahman et al. (2019) tried to examine the relationship between monetary policy and the economic development of Bangladesh by using multiple regressions. The study identified that the monetary policy of Bangladesh has a significant impact on the economic development of Bangladesh. Islam et al. (2018) found that several monetary policy tools such as variable reserve ratio, flexibility in rationing of credit and fixation of less margin requirement are significantly influencing the economic growth of Bangladesh.

Bank rate, money supply and lending interest act as essential instrumental factors of monetary policy. The bank rate has remained constant level in Bangladesh over the last 17 years. The maximum bank rate remained 10.75\% in Bangladesh from 1986 to 1989. Over the last 22 years, the money supply is increasing substantially from 1996 to 2018 . In 2019, the lending interest rate for Bangladesh was $9.56 \%$ (World Bank, 2020). Though Bangladesh's lending interest rate fluctuated in recent years, it tended to decrease through the 2000-2019 period (Figure 1). An expansionary monetary policy also influences the nominal exchange rate. For example, over the last 20 years, the exchange rate has grown substantially in Bangladesh. The highest exchange rate was 84.45 in 2019 (Figure 1). For this reason, the increasing trend indicates that the exchange rate acts as a powerful instrument of monetary policy in Bangladesh. The highest gross domestic product (GDP) growth rate for Bangladesh was $8.153 \%$ within the year from 1980 to 2019. However, the GDP growth rate fluctuated substantially in the early years since the emancipation of Bangladesh (Figure 1).

\subsection{Monetary policy and economic growth of the United Kingdom}

Numerous studies have been conducted mentioning the monetary policy of the UK. Bunn et al. (2018) estimated the impacts of UK monetary policy between 2008 and 2014, and found the minimal effect of monetary policy on standard relative income and wealth inequality measures. Argitis and Pitelis (2001) attempted to study monetary policy and income distribution with the evidence from the USA and the UK. They illuminated the issues surrounding the effects of monetary policy on changes in industrial capital income shares, financial capital and labor in the nonfinancial business sector. Money supply acts as a significant factor of monetary policy that influences the economic growth of the UK (Agbonlahor, 2014). It increased over twenty years from 1980 to 2008 and remained constant from 2008 to 2016 (Figure 2a). The bank of England sets the bank rate of the UK. The bank rate fluctuated from 1980 to 2009, although it remained stable in recent years (Figure 2c). Meanwhile, the highest lending interest rate was $16.313 \%$ in 1980 and hit a record low of $0.500 \%$ in 2014 . The exchange rate of the UK with respect to USD has dominated strongly over the timespan. The GDP growth rate of the UK fluctuated in recent years and was inclined to decrease from 2001 to 2019. In 2019, real GDP growth for the UK was around $1.463 \%$.

\subsection{Research gap and objectives of this study}

Rarely any empirical approach aimed to demonstrate the role of monetary policy and its impact on the economic growth of Bangladesh and the UK using the data of a long period. 


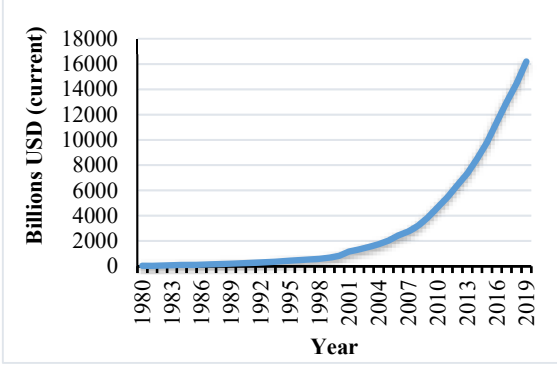

(a)

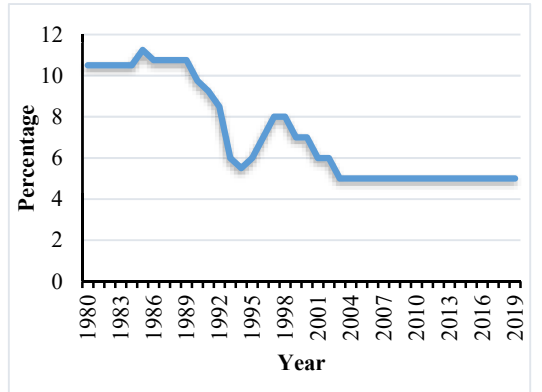

(c)

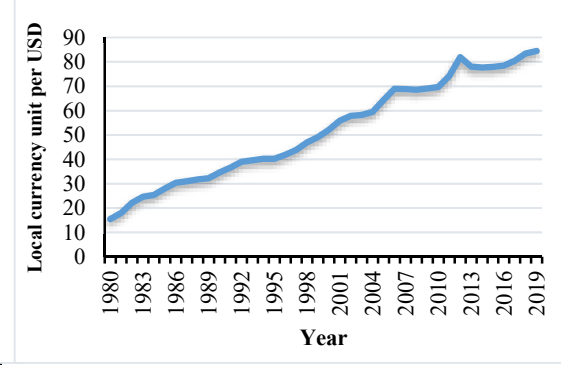

(b)

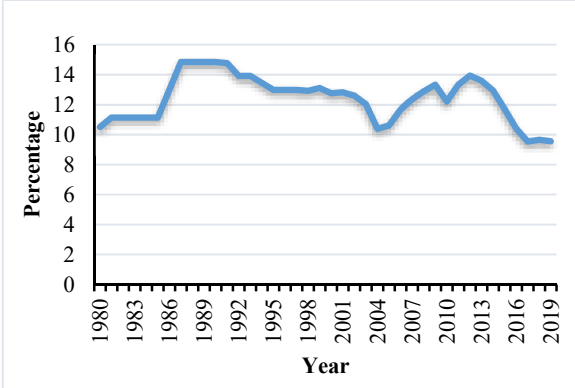

(d)

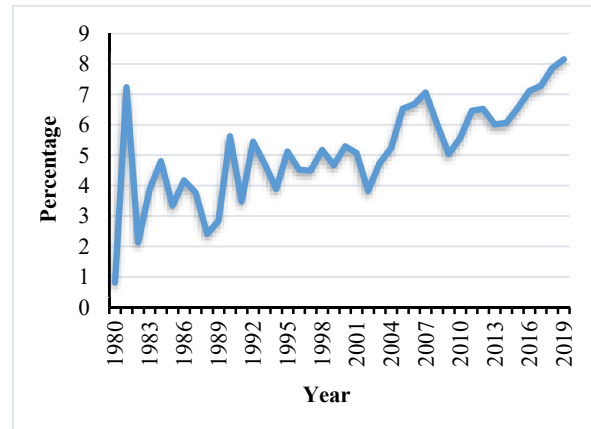

(e)

Source(s): World Bank (2020), International Monetary Fund (2020)

Figure 1. Trends of monetary policy instruments and economic growth in Bangladesh (a) Money supply (b) Exchange rate $(\mathrm{c})$ Bank rate $(\mathrm{d})$ Lending interest rate (e) GDP growth

Besides, there is hitherto scanty contemporary research on the direction of causality analysis of monetary policy and economic growth, taking Bangladesh and the UK into account. Also, none of the existing literature made any attempt to elucidate any comparative scenario of the role of the monetary policy in economic growth, including a developing nation like Bangladesh and a developed country like the UK. To satiate this gap, and to help generate the best policy recommendation, our study aims to adopt a dynamic auto-regressive distributed lag (ARDL) model, with the cognizance of the unit-root test to assess the long-run and shortrun impact of monetary policy on economic growth, as well as the VECM Granger causality among instruments of monetary policy and economic growth to determine the direction of causality among studied variables. 


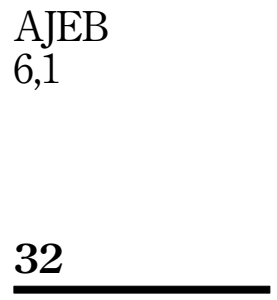

Figure 2 .

Trends of monetary policy instruments and economic growth in the UK (a) Money supply (b) Exchange rate (c) Bank rate (d) Lending interest rate (e) GDP growth

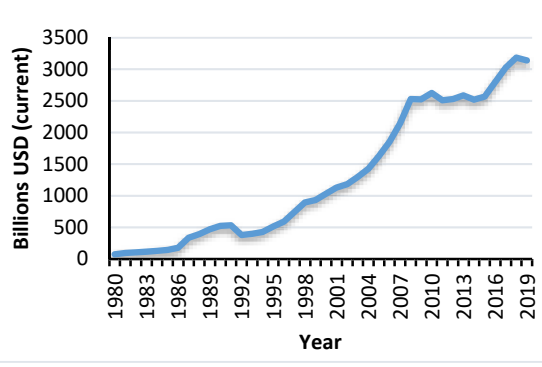

(a)

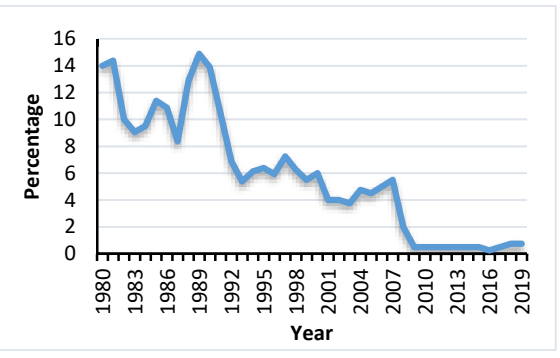

(c)

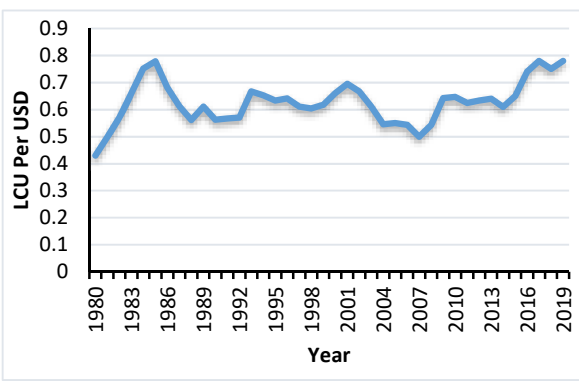

(b)

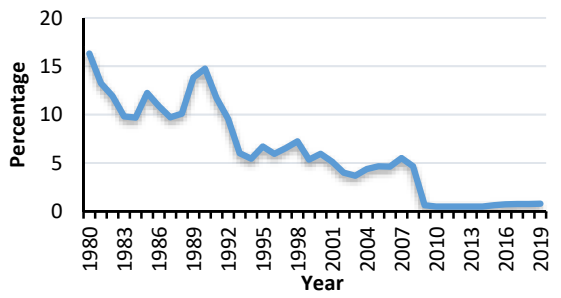

(d)

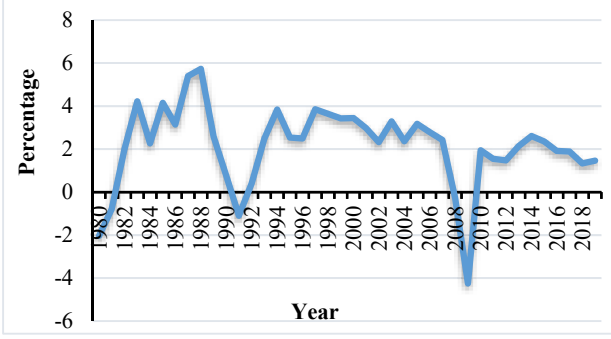

(e)

Source(s): World Bank (2020), International Monetary Fund (2020)

\section{Methodology}

\subsection{Data and variables}

The study employed all the latest secondary data extracted from the World Bank and the International Monetary Fund websites on annual time series data ranging from 1980 to 2019. This study selected Bangladesh and the UK as a developing and developed country, respectively. To satisfy the objectives of the study, we considered five variables. Due to the limitation of data availability, this study considered only four instruments of monetary policy. Monetary policy was represented by money supply (M2), bank rate, lending interest rate and exchange rate. Money supply (M2) is the volume of nonbank currency; demand for deposits other than those of the central government; time, savings, and foreign currency deposits of resident sectors other than the central government; bank and traveler's checks; and other securities such as commercial paper certificates and deposit (World Bank, 2020). The exchange rate corresponds to the local currency units relative to the US dollar. The bank 
rate is the interest rate at which a central bank advances loans to domestic/commercial banks. The lending interest rate is the rate at which commercial banks lend money to investors, private sectors, or other banks. Whereas, GDP growth rate is used as a proxy variable for economic growth, GDP growth rate acts as a dependent variable which was measured in terms of real GDP growth percentage. Table 1 presents the detailed description of the variables used in this study.

\subsection{Methods of data analysis and modeling}

Before proceeding with the inferential analysis, the study presented descriptive statistics results with mean, median, standard deviation, maximum and minimum of each variable. Further, a correlation matrix was examined for each variable to delineate the relationship among the variables.

The ARDL model requires every series or variable to be stationary at level, or first difference or amalgam of both. However, this dynamic model cannot be applicable if any series is stationary at the 2nd difference. Hence, to fulfill these prerequisites, we ran the Augmented Dickey-Fuller (ADF) (Dickey and Fuller, 1979) and Phillips-Perron (PP) (Phillips and Perron, 1988) tests for checking the unit-root properties of the studied variables. Following the outcome of the unit-root tests, we forwarded then to the ARDL model.

This study employed a level-log regression model to obtain the study objectives by transforming all the independent variables to a natural logarithmic form, excluding the dependent variable GDP growth rate. Natural logarithmic transformation linearized the independent variables. The reason behind not incorporating GDP growth to natural $\log$ form is that GDP growth for a country can be negative in any particular period that makes log transformation impossible in mathematical terms. To slide this uncertainty, this study chooses to run the following ARDL model, introduced by Pesaran and Shin (1995), which entails both long-run and short-run impact of underlying independent variables on the dependent variable. Thus, the empirical model can be specified as follows:

$$
\begin{aligned}
\Delta \mathrm{GDP}_{t}= & \alpha_{0}+\sum_{i=1}^{n} \alpha_{1 i} \Delta \mathrm{GDP}_{t-i}+\sum_{i=1}^{n} \alpha_{2 i} \Delta \mathrm{LNMS}_{t-i}+\sum_{i=1}^{n} \alpha_{3 i} \Delta \mathrm{LNBR}_{t-i} \\
& +\sum_{i=1}^{n} \alpha_{4 i} \Delta \mathrm{LNLIR}_{t-i}+\sum_{i=1}^{n} \alpha_{5 i} \Delta \mathrm{LNER}_{t-i}+\beta_{1} \mathrm{GDP}_{t-1}+\beta_{2} \mathrm{LNMS}_{t-1} \\
& +\beta_{3} \mathrm{LNBR}_{t-1}+\beta_{4} \mathrm{LNLIR}_{t-1}+\beta_{5} \mathrm{LNER}_{t-1}+u_{t}
\end{aligned}
$$

\begin{tabular}{|c|c|c|c|c|}
\hline Variables & $\begin{array}{l}\text { Unit of } \\
\text { measurement }\end{array}$ & Source & Remarks & Justification \\
\hline $\begin{array}{l}\text { Gross Domestic } \\
\text { Product (GDP) } \\
\text { growth rate }\end{array}$ & Percentage & World Bank & $\begin{array}{l}\text { Economic } \\
\text { growth }\end{array}$ & $\begin{array}{l}\text { Kapaya (2020), Nouri and } \\
\text { Samimi (2011), Akalpler and } \\
\text { Duhok (2018) }\end{array}$ \\
\hline $\begin{array}{l}\text { Money Supply } \\
\text { (M2) (MS) }\end{array}$ & $\begin{array}{l}\text { US Dollar } \\
\text { (current) }\end{array}$ & World Bank & $\begin{array}{l}\text { Monetary } \\
\text { policy }\end{array}$ & $\begin{array}{l}\text { Gnahe and Huang (2020), Li et al } \\
\text { (2010), Onyeiwu (2012), Fasanya } \\
\text { et al. (2013), Srithilat et al. (2017) }\end{array}$ \\
\hline Bank Rate (BR) & Percentage & $\begin{array}{l}\text { International } \\
\text { Monetary Fund }\end{array}$ & $\begin{array}{l}\text { Monetary } \\
\text { policy }\end{array}$ & $\begin{array}{l}\text { Bondarchuk and Raboshuk } \\
\text { (2020), Kamaan (2014) }\end{array}$ \\
\hline $\begin{array}{l}\text { Lending Interest } \\
\text { Rate (LIR) }\end{array}$ & Percentage & World Bank & $\begin{array}{l}\text { Monetary } \\
\text { policy }\end{array}$ & $\begin{array}{l}\text { Kamaan (2014), Rahman et al. } \\
\text { (2019), Tule et al. (2018) }\end{array}$ \\
\hline $\begin{array}{l}\text { Exchange Rate } \\
\text { (ER) }\end{array}$ & $\begin{array}{l}\text { Local currency } \\
\text { unit per USD }\end{array}$ & World Bank & $\begin{array}{l}\text { Monetary } \\
\text { policy }\end{array}$ & $\begin{array}{l}\text { Gnahe and Huang (2020), Gul } \\
\text { et al. (2012), Precious and } \\
\text { Makhetha-Kosi (2014) }\end{array}$ \\
\hline
\end{tabular}

Monetary
policy and
economic
growth

Table 1. Description of the variables 
AJEB

6,1

Here, GDP = gross domestic product growth rate; LNMS = natural log of money supply (M2); $\mathrm{LNBR}=$ natural $\log$ of bank rate; LNLIR = natural log of lending interest rate; LNER = natural log of exchange rate. $\alpha_{0}$ is the intercept; $\alpha_{1,} \alpha_{2}, \alpha_{3}, \alpha_{4}$ and $\alpha_{5}$ denote short-run coefficients; $\beta_{1,} \beta_{2,} \beta_{3,} \beta_{4}$, and $\beta_{5}$ define the long-run coefficients; $\mu_{\mathrm{t}}$ denotes error term.

The ARDL approach requires appropriately selected lags for each variable of the regression model. The optimal lag selection criterion produces the most compatible outcome of the model. Based on Akaike information criterion, optimal lag was chosen for each model. After running the ARDL model, the F-bounds test introduced by Pesaran et al. (2001) was conducted to testify the presence of a long-run association among the variables (Shahbaz et al., 2018). If the $F$-statistic is greater than the critical value of upper bound I(1) and lower bound $\mathrm{I}(0)$ at a $1 \%$ significance level, then the long-run relationship exists among variables. If $F$-statistic falls below the critical values I( 0$)$ and I(1) at a $1 \%$ level of significance, no long-run relationship exists. And if $F$-statistic lies between the critical values of $\mathrm{I}(0)$ and $\mathrm{I}(1)$ at a $1 \%$ level of significance, then it refers to be inconclusive (Kapaya, 2020). After employing the $F$-bounds approach, long-run coefficients were derived for the model (1). Thereafter, exploring long-run coefficients, this study drove the error correction model to obtain shortrun coefficients and error correction terms.

Further, we employed the vector error correction model (VECM) Granger causality test to check the causality direction among the variables examined. The ARDL model entails the effects of the independent variables on the dependent variable, but it does not convey any evidence regarding the direction of long-run and short-run causality among the variables examined. The VECM approach overcomes this obstacle. The VECM approach to assess the causality between variables assimilates the following model.

$$
\left[\begin{array}{c}
\mathrm{GDP} \\
\mathrm{LNMS} \\
\mathrm{LNER} \\
\mathrm{LNBR} \\
\mathrm{LNLIR}
\end{array}\right]=\left[\begin{array}{l}
\gamma_{1} \\
\gamma_{2} \\
\gamma_{3} \\
\gamma_{4} \\
\gamma_{5}
\end{array}\right]+\left[\begin{array}{llll}
\theta_{11 k} & \theta_{12 k} & \theta_{13 k} & \theta_{14 k} \\
\theta_{21 k} & \theta_{22 k} & \theta_{23 k} & \theta_{24 k} \\
\theta_{31 k} & \theta_{32 k} & \theta_{33 k} & \theta_{34 k} \\
\theta_{41 k} & \theta_{42 k} & \theta_{43 k} & \theta_{44 k} \\
\theta_{51 k} & \theta_{52 k} & \theta_{53 k} & \theta_{54 k}
\end{array}\right]\left[\begin{array}{c}
\Delta \mathrm{GDP} \\
\Delta \mathrm{LNMS} \\
\Delta \mathrm{LNER} \\
\Delta \mathrm{LNBR} \\
\Delta \mathrm{LNLIR}
\end{array}\right]+\left[\begin{array}{c}
\delta_{1} \\
\delta_{2} \\
\delta_{3} \\
\delta_{4} \\
\delta_{5}
\end{array}\right]\left(\mathrm{ECT}_{t-1}\right)+\left[\begin{array}{c}
\varepsilon_{1 i} \\
\varepsilon_{2 i} \\
\varepsilon_{3 i} \\
\varepsilon_{4 i} \\
\varepsilon_{5 i}
\end{array}\right]
$$

Besides, residuals play an imperative role in regression analysis. Residuals of the time series model should be homoscedastic, normally distributed and free of serial correlation. If the models pass all these three criteria, then they are valid. The Jarque-Bera test was employed to check the normality of the residuals. The Jarque-Bera test provides chi-square statistics. If the $p$-value of the Jarque-Bera test exceeds 0.05 , then the residuals are considered normally distributed. The serial correlation Lagrange multiplier (LM) test was conducted to verify the serial correlation of the residuals. The null hypothesis of the LM test is that there is no serial correlation up to lag order $k$, whereas $k$ is pre-specified. Lastly, Breusch-Pagan-Godfrey's test for heteroskedasticity was employed to justify the presence of heteroskedasticity of the residuals.

Finally, the cumulative sum (CUSUM) test and the CUSUM of squares test were carried out to examine the stability of the parameters of each respective model. The CUSUM test plots the cumulative sum together with the $5 \%$ critical lines. If the cumulative sum remains between the lines, the parameters are deemed stable. Similarly, the CUSUM of squares plots the cumulative sum of squares together with the $5 \%$ critical lines. The movement of the parameters inside the critical lines proves parameter stability. 


\section{Results and discussions}

\subsection{Descriptive statistics and correlation analysis}

The total observations of all the variables are 40 . With a standard deviation value of 1.613 for Bangladesh and 1.888 for the UK, the mean value of Bangladesh's GDP growth rate is higher than that of the UK (Table 2). It is also evident that Bangladesh's GDP growth in the last 40 years has always been positive, compared to the UK, with the lowest ever GDP growth of -4.248 . Bangladesh occupies a higher position in terms of money supply at the local currency unit, having a larger standard deviation than the UK, which symbolizes that Bangladesh has profoundly fluctuated its money supply strategy. Further, when it comes to the exchange rate, Bangladesh experiences a higher conversion rate with the US Dollar, implying that Bangladesh had a lower monetary value than the UK. The mean value for the bank rate in Bangladesh exceeds that of the UK, meaning that over the years, Bangladesh continued a higher bank rate compared to the UK. However, a higher standard deviation in the case of the UK elucidates the greater variability in the bank rate policy. The lending interest rate of Bangladesh provides a higher mean value. In contrast to the lending interest rate of Bangladesh, the UK has created tremendous deviations over the years, similar to the bank rate. However, apart from economic growth, all the variables are positively skewed, while the lending interest rate of Bangladesh is negatively skewed. All the estimated kurtosis values are less than three in absolute terms, suggesting that the variables are platykurtic. Evidence of normality exists in all the variables except GDP growth rate for the UK and money supply for Bangladesh, as the probability values of the other variables are well above $5 \%$, which is desirable.

The correlation analysis helps the researchers to define the correlation between the various variables that may affect the contribution of the investigated independent variables (Sarwar et al.,2020). Results from the correlation matrix report that the money supply and the exchange rate positively correlate with GDP growth, whereas the bank rate and the lending interest rate have a negative correlation with GDP growth in Bangladesh (Table 3). Similarly, for the UK, all the independent variables except lending interest rate provide the same shreds of evidence of positive correlation with GDP growth. Considering the outcome of the correlation matrix, we can infer that money supply, exchange rate, bank rate and lending interest rate are correlated with GDP growth rate to a random extent in both countries. Against this backdrop, the value of correlation coefficients between independent variables (money supply, exchange rate, bank rate and lending interest rate) was below the threshold value of 0.80 , which means our dataset is free of multicollinearity problems (Farrar and Glauber, 1967).

Table 4 demonstrates the results of unit roots tests. The unit root tests were executed to make sure that no I(2) variable(s) remain in the analysis (Nathaniel, 2020). Results of the ADF test showed that neither of the study variables for Bangladesh and the UK is stationary at the 2nd difference. As for Bangladesh, it depicts that underlying variables are integrated at mixed order of at level and 1st difference. Apart from GDP and LNER, all the variables are stationary at 1st difference for Bangladesh, while only GDP is stationary at the level for the UK. Hence, the outcomes advocate the ARDL model application eligibility for both Bangladesh and the UK cases. To consolidate the findings obtained from the ADF test, we further applied the Phillips-Perron test. The outcome goes in line with the result of the ADF test. Hence, we proceeded to run the ARDL model.

\subsection{Optimal lag selection, F-Bounds test and long-run relationship}

Before performing the ARDL model, we selected the optimal lag based on Akaike information criteria for developing the best model. Figure 3 shows that the ARDL model $(1,3,3,3,1)$ for Bangladesh and ARDL model $(3,2,3,3,4)$ for the UK exhibited are the most appropriate models. 
AJEB
6,1

36

Table 2.

Descriptive statistics of all variables (without logarithm)

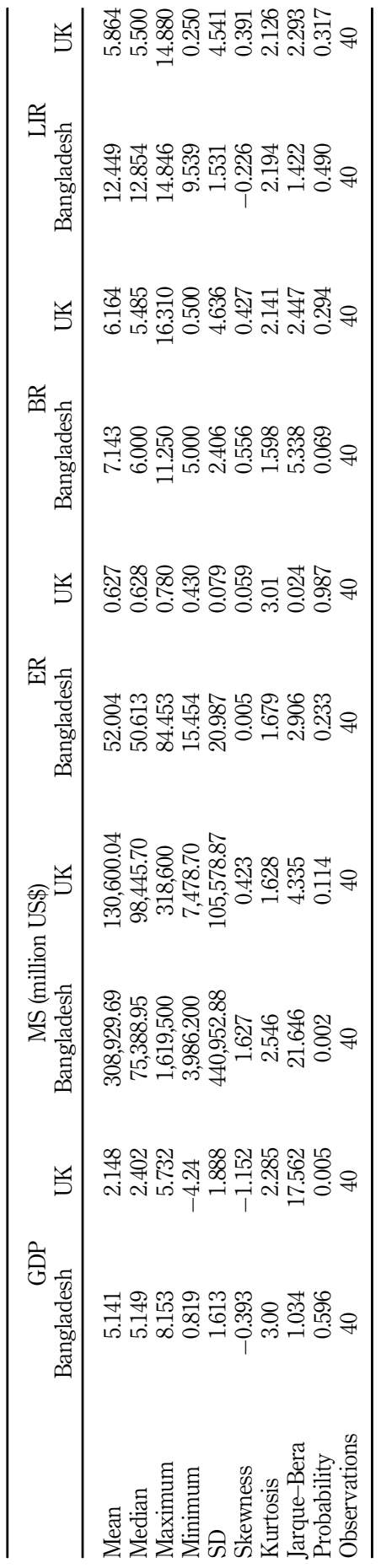




\begin{tabular}{|c|c|c|c|c|c|c|}
\hline & GDP & LNMS & LNER & LNBR & LNLIR & Monetary \\
\hline \multicolumn{6}{|c|}{ Bangladesh } & economic \\
\hline GDP & 1 & & & & & growth \\
\hline LNMS & $0.695^{*}$ & 1 & & & & \\
\hline LNER & $0.754^{*}$ & $0.607 *$ & 1 & & & \\
\hline LNBR & $-0.667^{*}$ & $-0.590 * *$ & -0.391 & 1 & & \\
\hline LNLIR & $-0.781^{* * *}$ & -0.491 & -0.250 & $0.223^{* *}$ & 1 & 37 \\
\hline \multicolumn{7}{|c|}{ United Kingdom } \\
\hline GDP & 1 & & & & & \\
\hline LNMS & $0.232^{*}$ & 1 & & & & \\
\hline LNER & $0.751^{* * *}$ & $0.282 * *$ & 1 & & & \\
\hline LNBR & $0.483^{* *}$ & $-0.569 *$ & -0.388 & 1 & & \\
\hline LNLIR & $-0.451^{* *}$ & -0.571 & -0.404 & $0.475^{* *}$ & 1 & Table 3. \\
\hline \multicolumn{6}{|c|}{ Note(s): $* *$ and $*$ denote statistically significant at 5 and $10 \%$ level of significance, respectively } & Correlation matrix \\
\hline
\end{tabular}

Table 5 shows that $F$-statistic exceeds the critical value of lower bound $\mathrm{I}(0)$ and upper bound I(1) at a $1 \%$ level of significance for both the Bangladesh and UK cases. It proves that monetary policy and economic growth move together in the long run for both countries. In other words, monetary policy has a long-run relationship with economic growth. These outcomes gain support from the previous studies (e.g. Tule et al., 2018; Ufoeze et al., 2018; Fasanya et al., 2013), where they revealed that monetary policy instruments have a long-run relationship with economic growth in Nigeria. Yet, some studies (e.g. Buigut, 2009; Ozer and Karagol, 2018) refuted that monetary policy and economic growth do not move together in the long run. As results from the $F$-bounds test endorse the existence of a long-run relationship among research variables, we advanced to derive the long-run coefficients.

Table 6 indicates that all the variables are statistically significant at a 5\% level except LNBR for Bangladesh. In contrast with the findings extracted for Bangladesh, all the variables proved to be statistically significant at a $1 \%$ level of significance for the UK, connoting the fact that all the variables have an intense impact on economic growth. The coefficient of LNMS is positive, meaning that other factors held constant, with an increase in money supply (M2), GDP growth rate proliferates in the long run in Bangladesh. Similarly, with an increase in money supply, the GDP growth rate spurs for the UK. This outcome is consistent with several previous studies (e.g. Gnahe and Huang, 2020; Hussain and Haque, 2017; Nouri and Samimi, 2011; Hameed, 2010; Ogunmuyiwa and Ekone, 2010; Muhammad et al., 2009). However, some (e.g. Awdeh, 2019) refuted this result. An increment in the money supply implies that more money is accessible for borrowing and lending in the economy; eventually, it lowers the cost of acquiring money. When it is simpler to get money, paces of consumption, investment and capital formulation will go up in general. Due to the availability of capital, people can invest in productive purposes for a longer period, without any pause. This is supported by the theory of the Tobin effect, which states that an addition to money supply will supplement capital formation, which in turn, will facilitate economic activities (Tobin, 1965). Also, it can correspond with the boost in the total output of an economy, and presumably, a country's GDP growth. Henceforth, although the nature of the economy of Bangladesh and the UK is different, money supply being a tool of formation in capital and expanding mobility has the same longrun impact on the growth. This may exhibit the significance of money supply irrespective of any nation to be a vital proponent of economic growth.

Added to that, unlike money supply(M2), the exchange rate exerts a negative long-run impact on GDP growth in Bangladesh, since LNER generates a coefficient of -1.949 , which 
AJEB
6,1

38

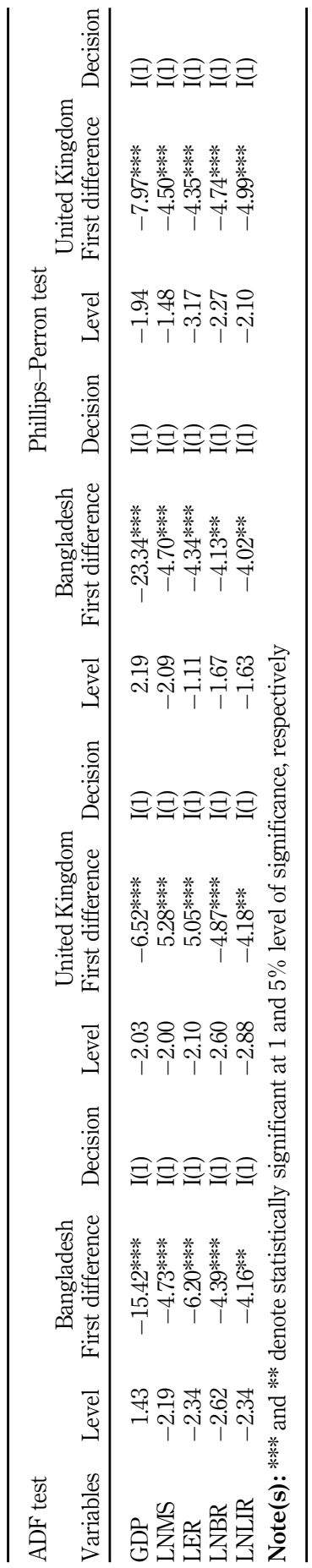

Table 4.

Unit root test for stationarity 


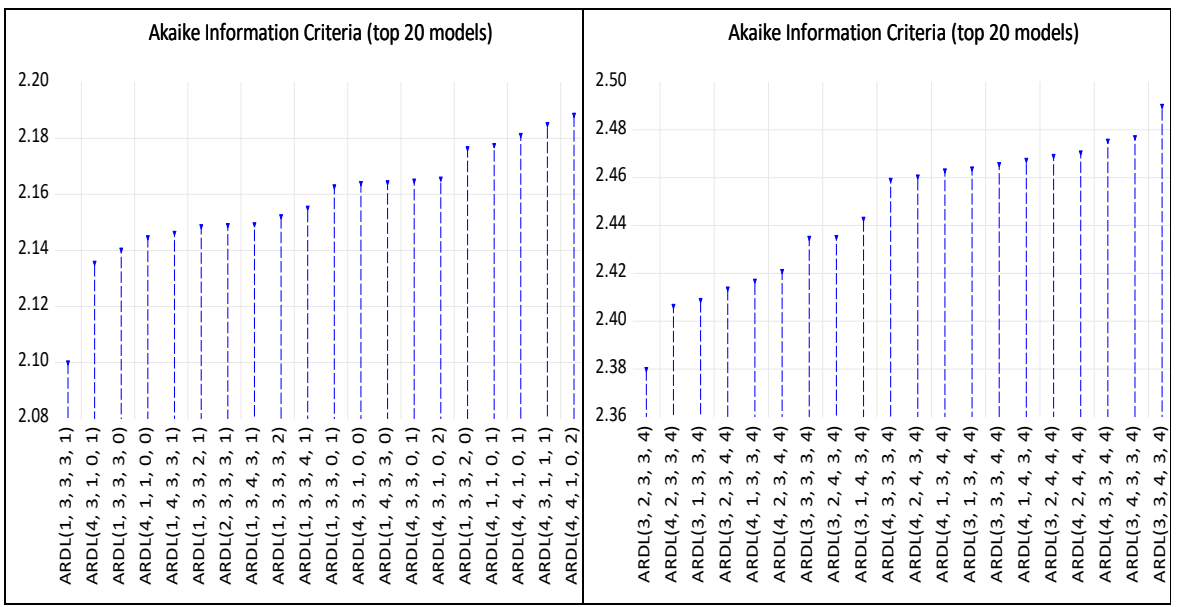

(a)

(b)
Monetary policy and economic growth

39

\begin{tabular}{lccccc}
\hline Country & $\begin{array}{c}F- \\
\text { stat }\end{array}$ & $\begin{array}{c}\text { Level of } \\
\text { significance }\end{array}$ & $\begin{array}{c}\text { Lower bound } \\
\mathrm{I}(0)\end{array}$ & $\begin{array}{c}\text { Upper bound } \\
\mathrm{I}(0)\end{array}$ & $\begin{array}{c}\text { Long run } \\
\text { association }\end{array}$ \\
\hline Bangladesh & \multirow{2}{*}{8.50} & $10 \%$ & 2.23 & 3.09 & Present \\
United & & $5 \%$ & 2.56 & 3.49 & Present \\
Kingdom & \multirow{2}{*}{11.27} & $2.5 \%$ & 2.88 & 3.87 & \\
\end{tabular}

Figure 3. Optimal lag selection for (a) Bangladesh (b) the United Kingdom

\begin{tabular}{lcccrrr}
\hline & & Bangladesh & & United Kingdom \\
Variables & Coefficient & Std. error & $t$-statistic & Coefficient & Std. error & $t$-statistic \\
\hline LNMS & $1.161^{* *}$ & 0.494 & 2.347 & $0.68^{* * * *}$ & 0.185 & 3.678 \\
LNER & $-1.949^{* *}$ & 0.812 & -2.386 & $-10.75^{* * *}$ & 1.497 & -7.179 \\
LNBR & -0.459 & 1.350 & -0.339 & $4.891^{* * *}$ & 0.784 & 6.235 \\
LNLIR & $-2.598^{* *}$ & 1.288 & -2.017 & $-4.234^{* * *}$ & 0.781 & -5.421 \\
\hline
\end{tabular}

Summary of the long-run findings

\begin{tabular}{lll} 
& & Impact on economic growth \\
& Bangladesh & United Kingdom \\
\hline LNMS & Positive & Positive \\
LNER & Negative & Negative \\
LNBR & Unexplainable & Positive \\
LNLIR & Negative & Negative
\end{tabular}

Note(s): *** and ** denote statistically significant at 1 and $5 \%$ level of significance, respectively

Table 6. Long-run coefficients

notifies that, other factors remaining unchanged, the GDP growth rate suffers in response to the upsurge in the exchange rate in the long run. It signifies that the economic growth of Bangladesh deteriorates with the rise in the exchange rate. The same finding can be found in a previous study (Fasanya et al., 2013) conducted in another developing country, that is, Nigeria. This finding can be ascribed to the negative trade balance of Bangladesh. 
AJEB

6,1

As Bangladesh imports more than what it exports, more money exits from the country than what it earns from export. A weak exchange rate would have geared up the economic growth to a new motion unless Bangladesh exported more than its import volume. Hence, a weak exchange rate shrinks the capital and eventually defers economic growth. The same results can be drawn from the UK, where an increase in the exchange rate proved to hurt economic growth. Likewise, in Bangladesh, the trade balance of the UK is negative, meaning that the UK imports more than its export. Besides, with a comparative strong exchange rate, the UK's goods become more expensive, decreasing exports. Consequently, it desists economic growth. Hence, from the findings of Bangladesh and the UK, it can be inferred that the overall economy suffers from an upsurge in the exchange rate due to the negative trade balance. This outcome is in harmony with previous findings (Srithilat et al., 2017; Fasanya et al., 2013). Although an increase in money supply (M2) engenders the risk of inflation, both economies of Bangladesh and the UK gain benefit from the money supply in the long run. Nonetheless, the excessive money supply should be controlled, and the Central Bank should decide on a perfect threshold level of the money supply to achieve sustained growth and limit the inflationary pressure. Immediate actions should be taken toward fixing the exchange rate and the lending interest rate decision for Bangladesh and the UK to prevent adverse effects on economic growth.

However, the coefficient of LNBR, which is statistically insignificant, even at a $10 \%$ level, signals that bank rate registers an insignificant causal impact on GDP growth in Bangladesh. This outcome partially goes in line with Ufoeze et al. (2018). Therefore, the effect of bank rates on economic growth is inconclusive for Bangladesh. On the other hand, the bank rate for the UK exhibits a positive relationship with economic growth. Henceforth, the uncertainty that the burgeoning bank rate may hamper economic growth is not true for the UK. Since the UK is a service-oriented economy, the increase in bank rate may well instigate the liability of the financial institutions and private banks, which may motivate them toward more profitoriented and less time-consuming actions that will amplify economic activities and promote growth around the country. Advanced economies like the UK had limited choice to reduce bank rates further and, hence, employed unconventional monetary policy tools such as quantitative easing to ensure sustainable economic growth (Venter, 2020).

The lending interest rate, another monetary policy indicator, showed a negative effect for both Bangladesh and the UK. Putting it simply, economic growth stumbles with the increase in lending interest rates. Evidently, the greater the magnitude of the lending interest rate, the slower the economic growth. This revelation is similar to the past findings (Amarasekara, 2008). In general, the rise in the lending interest rate also uplifts the cost of borrowing, resulting in a contraction in investment within the economy (Mushtaq and Siddiqui, 2016). Consequently, a lower level of investment stagnates the economic growth of the country. The financial market of Bangladesh is composed of both public and private investment through banking sectors, where lending interest rates have a substantial effect on household savings mobilization and on making investment decisions. An uptick in lending interest rates will damp the aggregate demand, investment and total output. Consequently, this creates a negative effect on economic growth. Similarly, an interest rate (lending or borrowing) cut may boost up the confidence of business people, investors and consumers for the long-run investment. Firms often may consider interest rates when determining whether or not to go further in long-run capital investment spending. A fall in interest rates may stimulate confidence and lead to an acceleration in planned capital investment and economic growth. Thus, higher lending interest rates result in lower growth, and lower lending interest rates introduce higher growth in the economy (Lee and Werner, 2018). Added to that, as the economic growth of the UK has remained more or less stable over the years, an uprising lending rate might lead its huge service industry to avoid taking credit, which, eventually, will curtail the investment. And as investment shrinks, the economy also suffers because of a lack of productivity and capital. 
4.3 Error correction model and short-run coefficients

Results plotted in Table 7 illustrate that in the short run, similar to the findings of Twinoburyo and Odhiambo (2018b), money supply up to lag two years hurts the economic growth in Bangladesh, unlike the UK, where money supply up to one lag year positively affects economic growth. The findings for the impact of money supply on economic growth in the UK go in tune with some studies (e.g. Jawaid et al., 2011; Ali et al., 2008). Meanwhile, the exchange rate in the current year showed a positive role in Bangladesh; however, no evidence of the impact of the current year's exchange rate on economic growth was found for the UK, which echoes the previous finding (Precious and Makhetha-Kosi, 2014). Further, the exchange rate with one lag year and two lag years seemed to thwart the economic growth in the UK. And in Bangladesh, the exchange rate back to two year fostered economic growth.

The bank rate in the current year and two years back showed an inverse effect on the economic growth for Bangladesh, whereas last year it stimulated economic growth. Oppositely, the current year's bank rate in the UK proved to impact economic growth positively, whereas the bank rate in the last year and two years back caused harm to the growth. These findings for Bangladesh and the UK partially match with the previous literature (Ozer and Karagol, 2018), where bank rates showed a negative short-run impact on economic growth in Turkey. Furthermore, the lending interest rate for the current year, last year and two years back hold a positive impact on the economic growth for the UK. However, in Bangladesh, the lending interest rate does not matter in short-run economic growth. This revelation reflects the previous study (Ufoeze et al., 2018). Besides, the error correction term (ECT) for models of Bangladesh and the UK is negative. This also validates the long-run relationship between the variables examined. The findings also denote that if there is a deviation from the initial equilibrium, 67 and $73 \%$ speed of adjustment is corrected yearly toward equilibrium for Bangladesh and the UK, respectively. The higher values of ECT are also indicating the robustness of our models.

\subsection{VECM Granger causality test}

Table 8 depicts that money supply, exchange rate, bank rate and lending interest rate jointly cause economic growth in Bangladesh. In addition, there appears to be a feedback association between money supply and economic growth both in the long run and short run. Hence,

\begin{tabular}{lccclcrr}
\hline Bangladesh & & & & & UK & \\
Variables & Coefficient & $\begin{array}{c}\text { Std. } \\
\text { error }\end{array}$ & $\begin{array}{c}t \text { - } \\
\text { statistic }\end{array}$ & Variables & Coefficient & $\begin{array}{c}\text { Std. } \\
\text { error }\end{array}$ & $\begin{array}{r}t \text { - } \\
\text { statistic }\end{array}$ \\
\hline D(LNMS) & $-4.071^{* *}$ & 1.719 & -2.367 & D(LNMS) & $5.585^{* * *}$ & 1.063 & 5.254 \\
D(LNMS(-1)) & $-0.437^{* *}$ & 0.193 & -2.257 & D(LNMS(-1)) & $1.816^{* * *}$ & 0.311 & 5.838 \\
D(LNMS(-2)) & $-6.952^{* * *}$ & 1.508 & -4.609 & D(LNER) & 6.896 & 4.486 & 1.537 \\
D(LNER) & $6.94^{* *}$ & 3.089 & 2.246 & D(LNER(-1)) & $-6.353^{* * *}$ & 2.057 & -3.088 \\
D(LNER(-1)) & 2.163 & 2.987 & 0.724 & D(LNER(-2)) & $-11.29^{* * *}$ & 3.408 & -3.313 \\
D(LNER(-2)) & $5.713^{* *}$ & 2.644 & 2.16 & D(LNBR) & $2.166^{* * *}$ & 0.369 & 5.874 \\
D(LNBR) & $-2.618^{* *}$ & 1.211 & -2.161 & D(LNBR(-1)) & $-6.976^{* * *}$ & 1.611 & -4.33 \\
D(LNBR(-1)) & $2.457^{*}$ & 1.289 & 1.905 & D(LNBR(-2)) & $-3.795^{* * *}$ & 0.464 & -8.179 \\
D(LNBR(-2)) & $-2.803^{* *}$ & 1.168 & -2.398 & D(LNLIR) & $1.002^{* * *}$ & 0.186 & 5.376 \\
D(LNLIR) & 1.567 & 1.865 & 0.84 & D(LNLIR(-1)) & $5.868^{* * *}$ & 2.917 & 2.012 \\
CointEq(-1)* & $-0.671^{* * *}$ & 0.084 & -7.944 & D(LNLIR(-2)) & $2.524^{* * *}$ & 0.446 & 5.653 \\
& & & & D(LNLIR(-3)) & $1.979^{* * *}$ & 0.499 & 3.968 \\
& & & & CointEq(-1)** & $-0.734^{* * *}$ & 0.165 & -4.439
\end{tabular}

Note(s): $* * *, * *$ and $*$ denote statistically significant at 1,5 and $10 \%$ level of significance, respectively

Monetary policy and economic growth

Error correction model with short-run coefficients 
AJEB

6,1

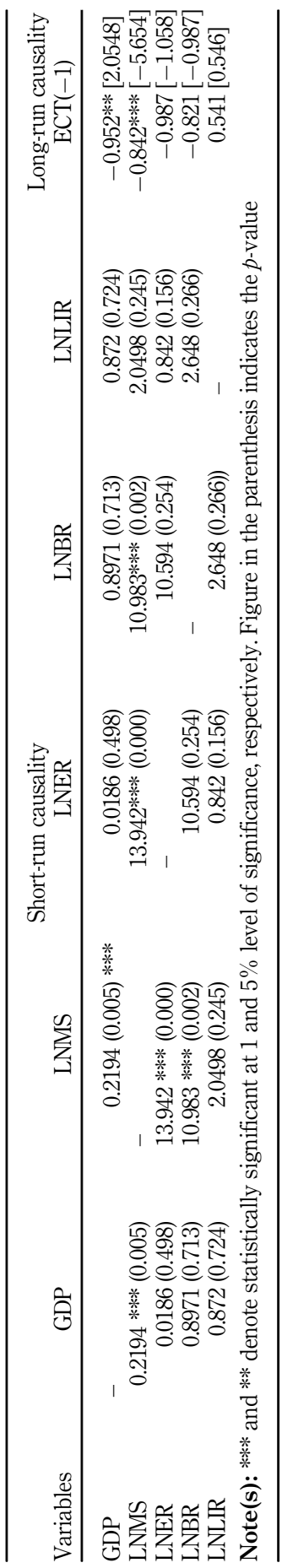

Table 8.

VECM granger

causality for

Bangladesh 
before implementing any long-term policy that may shape money supply and economic growth, the authority should be more cautious as both money supply and economic growth can affect each other. Further, short-run bidirectional causality relationships were revealed between (1) exchange rate and money supply; (2) bank rate and money supply. Putting it simply, money supply seems to impact bank rate and exchange rate with feedback effect. Therefore, it will be prudent for the monetary authority of Bangladesh to consider the consequences in the financial system before enacting any policy regarding money supply, bank rate, and exchange rate.

Unlike the case of Bangladesh, as depicted in Table 9, unidirectional long-run causality was found between money supply and economic growth in the UK, which means that making any change in money supply will not have any reciprocal effect on economic growth. However, short-run bidirectional causality was revealed between money supply and monetary policy, as well as between bank rate and money supply.

\subsection{Model robustness}

Results in Table 10 indicate that residuals have passed all the diagnostics tests for both Bangladesh and the UK models. Residuals are normally distributed, free of serial correlation and free of heteroskedasticity problems. Hence, our regression models are tenable. Results also depict that the values of $R$-squared and adjusted $R$-squared are satisfactory. DurbinWatson statistic shows no sign of the first-order autocorrelation, both in the contexts of Bangladesh and the UK. The $F$-statistic is also statistically significant. Therefore, we infer that our models are well-fitted.

Figure 4 shows the CUSUM test and the CUSUM squares test results for the ARDL model of Bangladesh and the UK. Findings illustrated the stability of the model and designated that parameters of the model for Bangladesh and the UK are embedded well inside the $5 \%$ critical lines. Hence, we infer that all the coefficients in the ARDL model are stable.

\section{Concluding remarks and policy implication}

Monetary policy has an imperative role in stabilizing the economy. This paper explores the impact of monetary policy on the economic growth in a developing country represented by Bangladesh and a developed country represented by the UK. The augmented Dickey-Fuller test and the Phillips-Perron test certified that no variable is stationary at 2nd difference. Further, the outcome of the $F$-bounds test confirmed that a long-run relationship exists among monetary policy variables and economic growth in both contexts. Afterward, long-run coefficients from the ARDL model revealed that money supply significantly propels economic growth in Bangladesh and the UK. It is discernible that an increase in the exchange rate and lending interest rate averts economic growth for both counties. Findings also depicted that, despite a rise in the bank rate, the economic growth of the UK stands tall. Lastly, the short-run coefficients revealed the random impact of all the variables at different lag periods, denoting the fact that monetary policy for both Bangladesh and the UK required to be implemented with a longterm plan to achieve sustained economic growth. A higher value of ECTs for both Bangladesh and the UK validates the robustness of the long-run relationship. Lastly, the VECM Granger causality approach delineated that while adopting policy reading money supply, the feedback effect should be born into consideration in the case of Bangladesh. It also visualized that money supply plays an imperative role in determining the economic growth for both Bangladesh and the UK.

This study comes up with some implications that the developing countries should pay heed to increase their money supply in the economy by controlling the inflation rate while devising their economic policies to improve employment opportunities and total output in
Monetary policy and economic growth

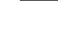


AJEB
6,1

44

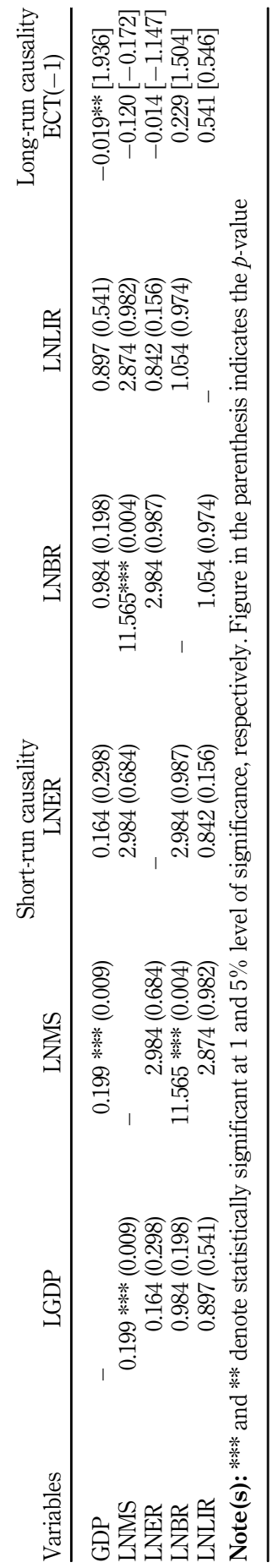

Table 9.

VECM granger

causality for the UK 


\begin{tabular}{|c|c|c|c|c|}
\hline Test & Bangladesh & $\begin{array}{l}\text { mates } \\
\text { United Kingdom }\end{array}$ & Remarks & $\begin{array}{l}\text { Monetary } \\
\text { policy and }\end{array}$ \\
\hline Jarque-Bera normality test & $\begin{array}{l}\text { Jarque-Bera stat }=1.68 \\
\text { Probability }=0.43\end{array}$ & $\begin{array}{l}\text { Jarque-Bera stat }=2.17 \\
\text { Probability }=0.33\end{array}$ & $\begin{array}{l}\text { Normal } \\
\text { distribution }\end{array}$ & $\begin{array}{l}\text { economic } \\
\text { growth }\end{array}$ \\
\hline $\begin{array}{l}\text { Breusch-Godfrey serial } \\
\text { correlation LM test }\end{array}$ & $\begin{array}{l}\text { Obs. } * R \text {-squared }=4.56 \\
\text { Prbh }\end{array}$ & $\begin{array}{l}\text { Obs. } * R \text {-squared }=5.55 \\
\text { Prob. chi-square }(1)=0.06\end{array}$ & $\begin{array}{l}\text { No serial } \\
\text { correlation }\end{array}$ & \\
\hline Heteroskedasticity test: & Obs. $* R$-squared $=14.36$ & Obs. $* R$-squared $=12.27$ & Homoscedastic & 45 \\
\hline Breusch-Pagan-Godfrey & Prob. chi-square $=0.49$ & Prob. chi-square $=0.87$ & & \\
\hline$R$-squared & 0.884 & 0.930 & & \\
\hline Adjusted $R$-squared & 0.802 & 0.848 & & Tabl \\
\hline Durbin Watson stat & 2.044 & 2.536 & & Outcomes of residuals \\
\hline$F$-statistic & 10.742 & 11.28 & & diagnostics test and \\
\hline Prob. of $F$-statistic & 0.000 & 0.000 & & model fitness \\
\hline
\end{tabular}

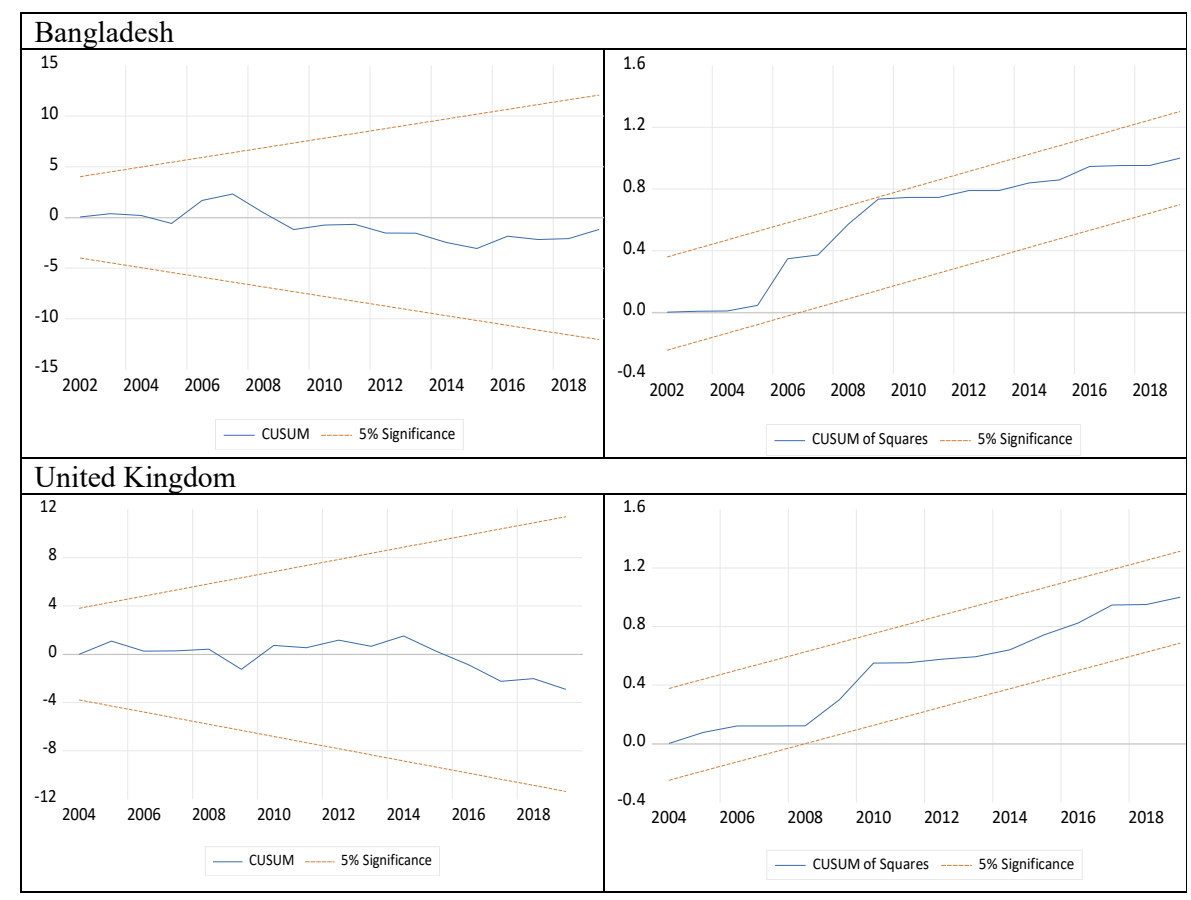

Figure 4.

Outcomes of the CUSUM and CUSUM squares tests

their countries. Since Bangladesh's currency value is not powerful enough in the global market, in order to strengthen the country's currency, the increase of export earning and trade facilities should be promoted, thus fostering economic growth. Furthermore, they should also attempt to lower the lending interest rate to promote investment and income, and hence, achieve positive economic growth. The lending interest rate in Bangladesh is now relatively high, with only a few specific schemes for productive investment at a lower rate. As a result, the lending interest rate should be kept reasonable to encourage productive investment and boost the country's economic growth. 


\section{AJEB}

6,1

\section{Limitations and further study directions}

Despite the fact that this study makes a substantial contribution to the extant literature, the following drawbacks should be noted. Due to data unavailability, the scope of the paper (i.e. the focus on one developing and one developed country) limits the extent to which the findings may be generalized, and it also emphasizes that applying the findings to other jurisdictions should be done with caution. As a result, upon data availability, future research should consider multiple developing and developed countries, utilizing a panel data analysis technique to determine if there are any changes in the results and allow for better generalization and applicability. Furthermore, future research can consider other monetary policy instruments, including the studied variables, to come up with more intact conclusions and policy implications.

\section{References}

Agbonlahor, O. (2014), "The impact of monetary policy on the economy of the United Kingdom: a Vector Error Correction Model (VECM)", European Scientific Journal, Vol. 10 No. 16, pp. 19-42.

Ahmed, S. and Islam, M.E. (2004), "The monetary transmission mechanism in Bangladesh: bank lending and exchange rate channels", The Bangladesh Development Studies, pp. 31-87.

Akalpler, E. and Duhok, D. (2018), "Does monetary policy affect economic growth: evidence from Malaysia”, Journal of Economic and Administrative Sciences, Vol. 34 No. 1, pp. 2-20.

Amarasekara, C. (2008), "The impact of monetary policy on economic growth and inflation in Sri Lanka”, Central Bank of Sri Lanka Staff Studies, Vol. 38, pp. 1-44.

Alam, M.R. (2015), "Effectiveness of monetary policy in Bangladesh", The Journal of Developing Areas, Vol. 49 No. 2, pp. 363-372.

Ali, S., Irum, S. and Ali, A. (2008), "Whether fiscal stance or monetary policy is effective for economic growth in case of South Asian Countries?", The Pakistan Development Review, pp. 791-799.

Angeriz, A. and Arestis, P. (2007), "Monetary policy in the UK", Cambridge Journal of Economics, Vol. 31 No. 6, pp. 863-884.

Arestis, P. and Sawyer, M.C. (2008), "A critical reconsideration of the foundations of monetary policy in the new consensus macroeconomic framework", Cambridge Journal of Economics, Vol. 32 No. 5, pp. 761-779.

Argitis, G. and Pitelis, C. (2001), "Monetary policy and income distribution: evidence from the USA and the UK", Journal of Post-Keynesian Economics, Vol. 23 No. 4, pp. 617-638.

Awdeh, A. (2019), "Monetary policy and economic growth in Lebanon", Journal of Central Banking Theory and Practice, Vol. 8 No. 2, pp. 147-171.

Backhouse, R.E. and Bateman, B.W. (2011), Capitalist Revolutionary, Harvard University Press, Cambridge, MA.

Barkawi, A. and Monnin, P. (2015), Monetary Policy and Sustainability. The Case of Bangladesh, Discussion Note, 1, CEP.

Bean, C.R. and Jenkinson, N. (2001), The Formulation of Monetary Policy at the Bank of England, Bank of England Quarterly Bulletin, Winter.

Bondarchuk, V. and Raboshuk, A. (2020), "The impact of monetary policy on economic growth in Ukraine”, Ekonomista, pp. 94-115.

Buigut, S. (2009), "Monetary policy transmission mechanism: implications for the proposed East African community (EAC) monetary union", in CSAE Conference.

Criste, A. and Lupu, I. (2014), "The central bank policy between the price stability objective and promoting financial stability", Procedia Economics and Finance, Vol. 8, pp. 219-225.

Dickey, D.A. and Fuller, W.A. (1979), "Distribution of the estimators for autoregressive time series with a unit root", Journal of the American Statistical Association, Vol. 74 No. 366a, pp. 427-431. 
Farrar, D.E. and Glauber, R.R. (1967), "Multicollinearity in regression analysis: the problem revisited", The Review of Economic and Statistics, pp. 92-107.

Fasanya, I.O., Onakoya, A.B. and Agboluaje, M.A. (2013), "Does monetary policy influence economic growth in Nigeria?", Asian Economic and Financial Review, Vol. 3 No. 5, p. 635.

Fourcans, A. and Vranceanu, R. (2007), “The ECB monetary policy: choices and challenges”, Journal of Policy Modeling, Vol. 29, pp. 181-194.

Friedman, B.M. (1990), "Targets and instruments of monetary policy", in Handbook of Monetary Economics, Elsevier, Amsterdam, Vol. 2, pp. 1185-1230.

Friedman, B.M. (2000), Monetary Policy, Working Paper No. 8057, National Bureau of Economic Research, doi: 10.3386/w8057.

Galí, J. (2015), Monetary Policy, Inflation, and the Business Cycle: An Introduction to the New Keynesian Framework and its Applications, Princeton University Press.

Gnahe, F.E. and Huang, F.M. (2020), "The effect of monetary policy on economy growth of WAEMU countries", Open Journal of Business and Management, Vol. 8 No. 6, pp. 2504-2523.

Gul, H., Mughal, K. and Rahim, S. (2012), "Linkage between monetary instruments and economic growth”, Universal Journal of Management and Social Sciences, Vol. 2 No. 5, pp. 69-76.

Hameed, D. (2010), "Impact of monetary policy on gross domestic product (GDP)", Interdisciplinary Journal of Contemporary Research in Business, Vol. 3 No. 1, pp. 1348-1361.

Hossain, M. and Ibon, M.W.F. (2020), "Assessing the effectiveness of monetary policy in Bangladesh", in Bangladesh's Macroeconomic Policy, Palgrave Macmillan, Singapore, pp. 135-162.

Hussain, M.E. and Haque, M. (2017), "Empirical analysis of the relationship between money supply and per capita GDP growth rate in Bangladesh", Journal of Advances in Economics and Finance, Vol. 2 No. 1, pp. 54-66.

International Monetary Fund (2020), International Financial Statistics, available at: International Financial Statistics - Reports - IMF Data (accessed on 25 November 2020).

Islam, M.S., Akter, M. and Sarker, M.S.I. (2018), "Economic growth in Bangladesh: impact of fiscal policy and monetary policy", Romanian Economic Business Review, Vol. 13 No. 2, pp. 45-57.

Jawaid, S.T., Qadri, F.S. and Ali, N. (2011), "Monetary-fiscal-trade policy and economic growth in Pakistan: time series empirical investigation", International Journal of Economics and Financial Issues, Vol. 1 No. 3, pp. 133-138.

Kamaan, C.K. and Nyamongo, E.M. (2014), "The effect of monetary policy on economic growth in Kenya", International Journal of Business and Commerce, Vol. 3 No. 8, pp. 11-24.

Kapaya, S.M. (2020), "Financial development and economic growth in Tanzania: an ARDL and bound testing approach”, Asian Journal of Economics and Banking, Vol. 5 No. 1, pp. 46-65.

Kareem, R.O., Afolabi, A.J., Raheemand, K.A. and Bashir, N.O. (2013), "Analysis of fiscal and monetary policies on economic growth: evidence from Nigerian democracy", Current Research Journal of Economic Theory, Vol. 5 No. 1, pp. 11-19.

Keynes, J.M. (1936), The General Theory of Employment, Interest and Money, Macmillan, London.

Lashkary, M. and Kashani, H.B. (2011), "The impact of monetary variables on economic growth in Iran: a monetarists' approach”, World Applied Sciences Journal, Vol. 15 No. 3, pp. 449-456.

Lee, K.S. and Werner, R.A. (2018), "Reconsidering monetary policy: an empirical examination of the relationship between interest rates and nominal GDP growth in the US, UK, Germany and Japan”, Ecological Economics, Vol. 146, pp. 26-34.

Li, Y.D., İşcan, T.B. and Xu, K. (2010), "The impact of monetary policy shocks on stock prices: evidence from Canada and the United States", Journal of International Money and Finance, Vol. 3 No. 5, pp. 876-896.
Monetary policy and economic growth 
AJEB

6,1

Mugableh, M.I. (2019), "Does monetary policy affect economic growth in Jordan? Evidence from ordinary least square models", International Business Research, Vol. 12 No. 1, pp. 27-34.

Muhammad, S.D., Wasti, S.K.A., Hussain, A. and Lal, I. (2009), "An empirical investigation between money supply government expenditure, output and prices: the Pakistan evidence", European Journal of Economics, Finance and Administrative Sciences No. 17 , p. 60.

Mushtaq, S. and Siddiqui, D.A. (2016), "Effect of interest rate on economic performance: evidence from Islamic and non-Islamic economies", Financial Innovation, Vol. 2 No. 1, pp. 1-14.

Mutuku, C. and Koech, E. (2014), "Monetary and fiscal policy shocks and economic growth in Kenya: VAR econometric approach”, Journal of World Economic Research, Vol. 3 No. 6, pp. 95-108.

Nathaniel, S.P. (2020), "Modelling urbanization, trade flow, economic growth and energy consumption with regards to the environment in Nigeria", GeoJournal, Vol. 85, pp. 1499-1513.

Noman, S.M.S. and Khudri, M.M. (2015), "The effects of monetary and fiscal policies on economic growth in Bangladesh”, ELK Asia Pacific Journal of Finance and Risk Management, Vol. 6 No. 3, pp. 21-34.

Nouri, M. and Samimi, A.J. (2011), "The impact of monetary policy on economic growth in Iran", Middle-East Journal of Scientific Research, Vol. 9 No. 6, pp. 740-743.

Ogunmuyiwa, M.S. and Ekone, A.F. (2010), "Money supply-economic growth nexus in Nigeria”, Journal of Social Sciences, Vol. 22 No. 3, pp. 199-204.

Onyeiwu, C. (2012), "Monetary policy and economic growth of Nigeria", Journal of Economics and Sustainable Development, Vol. 3 No. 7, pp. 62-70.

Ozer, M. and Karagol, V. (2018), "Relative effectiveness of monetary and fiscal policies on output growth in Turkey: an ARDL bounds test approach Equilibrium", Quarterly Journal of Economics and Economic Policy, Vol. 13 No. 3, pp. 391-409.

Pesaran, M.H. and Shin, Y. (1995), "An autoregressive distributed lag modeling approach to cointegration analysis".

Pesaran, M.H., Shin, Y. and Smith, R.J. (2001), "Bounds testing approaches to the analysis of level relationships", Journal of Applied Econometrics, Vol. 16 No. 3, pp. 289-326.

Pettinger, T. (2020), "UK Monetary policy”, Economics, Help, available at: https://www.economicshelp. org/macroeconomics/monetary-policy/ (accessed on 23 January 2021).

Phillips, P.C. and Perron, P. (1988), "Testing for a unit root in time series regression”, Biometrika, Vol. 75 No. 2, pp. 335-346.

Precious, C. and Makhetha-Kosi, P. (2014), "Impact of monetary policy on economic growth: a case study of South Africa”, Mediterranean Journal of Social Sciences, Vol. 5 No. 15, pp. 76-84.

Rahman, M., Nower, N., Tushar, R.H., Abbas, S.M. and Musa, M.N. (2019), "Impact of monetary policy on the economic growth of a developing country: an empirical study on Bangladesh economy", doi: 10.2139/ssrn.3391280 (accessed 30 January 2021).

Sarwar, A., Khan, M.A., Sarwar, Z. and Khan, W. (2020), "Financial development, human capital and its impact on economic growth of emerging countries", Asian Journal of Economics and Banking, Vol. 5 No. 1, pp. 86-100.

Shah, S. (2009), Bangladesh Financial Sector: An Agenda for Further Reforms, Asian Development Bank, Mandaluyong City.

Shahbaz, M., Naeem, M., Ahad, M. and Tahir, I. (2018), "Is natural resource abundance a stimulus for financial development in the USA?", Resources Policy, Vol. 55, pp. 223-232.

Srithilat, K., Sun, G. and Thavisay, M. (2017), "The impact of monetary policy on economic development: evidence from Lao PDR”, Global Journal of Human-Social Science Research, Vol. 17 No. 2, pp. 9-15. 
Tobin, J. (1965), "Money and economic growth”, Econometrica, Vol. 33, pp. 671-678.

Tule, M.K., Ogundele, O.S. and Apinran, M.O. (2018), "Efficacy of monetary policy instruments on economic growth: evidence from Nigeria”, Asian Economic and Financial Review, Vol. 8 No. 10, pp. 1239-1256.

Twinoburyo, E.N. and Odhiambo, N.M. (2018a), "Monetary policy and economic growth: a review of international literature", Journal of Central Banking Theory and Practice, Vol. 7 No. 2, pp. 123-137.

Monetary

policy and economic

growth

Twinoburyo, E.N. and Odhiambo, N.M. (2018b), "Can Monetary Policy drive economic growth? Empirical evidence from Tanzania”, Contemporary Economics, Vol. 12 No. 2, pp. 207-222.

Ufoeze, L.O., Odimgbe, S.O., Ezeabalisi, V.N. and Alajekwu, U.B. (2018), "Effect of monetary policy on economic growth in Nigeria: an empirical investigation", Annals of Spiru Haret University, Economic Series, Vol. 9 No. 1, pp. 123-140.

Venter, Z. (2020), "The interaction between conventional monetary policy and financial stability: Chile, Colombia, Japan, Portugal and the UK", Comparative Economic Studies, Vol. 62 No. 3, pp. 521-554.

World Bank (2020), Macroeconomic Indicators of Bangladesh and United Kingdom, available at: Bangladesh | Data (worldbank.org) United Kingdom | Data (worldbank.org) (accessed 25 November 2020).

\section{Corresponding author}

Md. Emran Hossain can be contacted at: emranaerd@gmail.com

For instructions on how to order reprints of this article, please visit our website:

www.emeraldgrouppublishing.com/licensing/reprints.htm

Or contact us for further details: permissions@emeraldinsight.com 